\title{
Meeting the challenge of mapping peatlands with remotely sensed data
}

\author{
O. N. Krankina ${ }^{1}$, D. Pflugmacher ${ }^{1}$, M. Friedl ${ }^{2}$, W. B. Cohen ${ }^{3}$, P. Nelson ${ }^{1}$, and A. Baccini ${ }^{2}$ \\ ${ }^{1}$ Oregon State Univ., Department of Forest Ecosystems and Society, 321 Richardson Hall, Corvallis, OR 97331, USA \\ ${ }^{2}$ Boston Univ., Department of Geography and Environment, 675 Commonwealth Ave., 4th Floor, Boston, MA 02215, USA \\ ${ }^{3}$ Forestry Sciences Laboratory, Pacific Northwest Research Station, USDA Forest Service, 3200 SW Jefferson Way, Corvallis, \\ OR 97331, USA
}

Received: 4 March 2008 - Published in Biogeosciences Discuss.: 16 May 2008

Revised: 25 November 2008 - Accepted: 25 November 2008 - Published: 23 December 2008

\begin{abstract}
Boreal peatlands play a major role in carbon and water cycling and other global environmental processes but understanding this role is constrained by inconsistent representation of peatlands on, or omission from, many global land cover maps. The comparison of several widely used global and continental-scale databases on peatland distribution with a detailed map for the St. Petersburg region of Russia showed significant under-reporting of peatland area, or even total omission. Analysis of the spatial agreement and disagreement with the detailed regional map indicated that the error of comission (overestimation) was significantly lower than the error of omission (underestimation) which means, that overall, peatlands were correctly classified as such in coarse resolution datasets but a large proportion (7499\%) was overlooked. The coarse map resolution alone caused significant omission of peatlands in the study region. In comparison to categorical maps, continuous field mapping approach utilizing MODIS sensor data showed potential for a greatly improved representation of peatlands on coarse resolution maps. Analysis of spectral signatures of peatlands with different types of surface vegetation suggested that improved mapping of boreal peatlands on categorical maps is feasible. The lower reflectance of treeless peatlands in the near- and shortwave-infrared parts of the electromagnetic spectrum is consistent with the spectral signature of sphagnum mosses. However, when trees are present, the canopy architecture appears to be more important in defining the overall spectral reflectance of peatlands. A research focus on developing remote sensing methods for boreal peatlands is needed for adequate characterization of their global distribution.
\end{abstract}

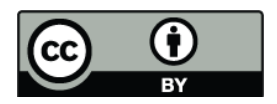

Correspondence to: O. N. Krankina (olga.krankina@oregonstate.edu)

\section{Introduction}

The lack of globally consistent mapping of peatlands is a major source of uncertainty in assessing their current role in the global carbon and water cycle and projecting their future change (Frey and Smith, 2007; Beilman et al., 2008). While the importance of peatlands is widely recognized, and there is a large body of research improving our understanding of processes and controls on $\mathrm{CO}_{2}$ and $\mathrm{CH}_{4}$ exchange (e.g. Frolking et al., 2006; Denman et al., 2007), there has been little progress in reducing uncertainty in the area, distribution, and carbon stores in peatlands globally. In fact, most publications addressing the potentially critical role of boreal peatlands in greenhouse gas emissions continue to reference Gorham (1991) and his estimate of carbon store in peatlands at $180-455 \mathrm{PgC}$ or about $1 / 3$ of the global soil carbon pool (e.g., Smith et al., 2004). A recent assessment revised the estimate of the total carbon pool in peatlands to $462 \mathrm{PgC}$ and their total area to 344 million ha while pointing out the inadequacy of data for many parts of the world (Bridgham et al., 2007), including permafrost regions (Sheng et al., 2004). Furthermore, these global estimates are compilations of regional datasets that use different classifications making their integration problematic. The development of globally consistent spatial data on distribution of peatlands is necessary for effective inclusion of peatlands into global biogeochemical models.

Northern peatlands are widely reported to experience the effects of climate change leading to changes in hydrology, vegetation cover, export of dissolved organic carbon, respiration and methane production (e.g., Sturm et al., 2001; McGuire et al., 2002; Pastor et al., 2003; Roulet, 2000). A strong positive feedback to global warming is expected in boreal permafrost peatlands where the evidence of permafrost melting is widely recognized (see review in Anisimov et al., 2007) and associated successional patterns of vegetation are

Published by Copernicus Publications on behalf of the European Geosciences Union. 
well established (i.e. lake formation and draining, characteristic shifts in plant species composition). However, global assessment of these patterns is lacking.

Mapping peatlands as a distinct type of land cover is challenging, which has lead to their omission from many global vegetation maps and inconsistent representation on others (Frey and Smith, 2007). Peatland is commonly defined as peat-covered terrain with a minimum depth of peat set between 30 and $50 \mathrm{~cm}$ by different classifications. Peat accumulates on land surface under more or less water-saturated conditions owing to anoxic environment, low decomposability of the plant material, and other causes (Rydin and Jeglum, 2006). In the boreal, sub-arctic and arctic zones, low temperature is a major factor that slows decomposition processes and virtually all vegetated wetlands have some peat accumulation. Since the direct estimation of peat depth with optical remote sensing is not possible, the mapping of peatlands usually utilizes proxy variables such as hydrological, geomorphological or floristic characteristic.

Because of the association of peatlands with watersaturated conditions, maps of wetlands are frequently used as a proxi. However, in the boreal zone a significant portion of peatlands does not experience prolonged inundation and global assessments that are focused on hydrological characteristics (e.g., Matthews, 1989; Prigent et al., 2007) can be expected to represent peatlands inadequately. Furthermore, the use of inundation as a proxi variable for mapping peatlands excludes drained peatlands that represent a large proportion of all peatlands in some regions. Several studies report successful mapping of wetlands with a combination of radar and optical sensors ( $\mathrm{Li}$ and Chen, 2005; Rosenqvist et al., 2007). The advantage of radar sensors compared to multispectral sensors is that they can penetrate cloud cover and that they are sensitive to variable soil moisture conditions. However, the lack of surface inundation during most of the growing season and variability of the water table over seasons and years is an obstacle for radar-based mapping of peatlands in the boreal zone. Many global land-cover maps either emphasize inundation in their classification of wetlands (e.g., IGBP, Friedl et al., 2002) or omit them completely (e.g., UMD, Hansen et al., 2000). Because of its global availability the Global Distribution of Wetlands product (Matthews and Fung, 1987) is often used to define the occurrence of peatlands in global and circumpolar carbon cycling models (e.g., McGuire et al., 2007). Thus the robustness of carbon balance estimates depends substantially on the capacity of this or other global proxi datasets to accurately represent the distribution of peatlands (Beilman et al., 2008).

Vegetation cover is another proxi variable commonly used for mapping peatlands, especially in the boreal zone where peatland conversion to agricultural use is limited at the southern fringe and virtually non-existent in permafrost regions (Sheng et al., 2004; Beilman et al., 2008). Boreal peatlands have a distinct canopy structure that comprises open tree canopy, a shrub layer, and a continuous layer of herbaceous vegetation with significant presence of mosses. Modern classifications of land cover based on physiognomic features of surface vegetation tend to focus on dominant life forms (e.g. Land Cover Classification System (LCCS), DiGregorio, 2005) and are not well suited to defining characteristic assemblages of several life forms. While it is possible to define waterlogged lands within the LCCS, the required level of detail would appear inappropriate for a global map. The global map based on LCCS classification (GLC2000) uses inundation as a defining feature of wetlands (Bartolome and Belward, 2005), but the contributing continental map for Northern Eurasia includes wetland definitions that are more appropriate for boreal peatlands: bogs and marsh, palsa bogs, and riparian vegetation (Bartalev et al., 2003). Considering the global significance of peatlands in carbon and water cycling and in sustaining biodiversity, it may be appropriate to put greater emphasis on characterisation of peatlands within the LCCS and global map legends.

In addition to difficulties in defining peatlands within the matrix of other land cover types, many peatlands are likely to be omitted from 1-km resolution categorical maps simply because of their small size. An approach that could overcome this limitation of categorical maps is known as continuous field modeling; it estimates sub-pixel proportions of land cover types from remote sensing data. Continuous field maps hold some advantages as they provide improved spatial detail when compared to categorical maps that by definition discretize landscapes. Unlike classifications, continuous cover maps enable users to define their own thresholds for landcover classes. Continuous field maps for forest cover have been developed for different regions in the world and from different sensor types, e.g. AVHRR (DeFries et al., 1997; Häme et al., 2001) and MODIS (Hansen et al., 2005). A continuous field map of peatland cover was created to capture the extent and distribution of peatlands in the St. Petersburg region of Russia using data from the Moderate Resolution Imaging Spectroradiometer (MODIS) (Pflugmacher et al., 2007). Improved representation of wetlands and other ecologically significant classes that occupy relatively small area has been recognized as an important objective for future global mapping and validation efforts (Herold et al., 2008).

Even though peat layer is not visible to optical satellite sensors, peatlands within the boreal forest zone are easy to identify visually on high and medium spatial resolution imagery such as Landsat TM/ETM+ $(30 \mathrm{~m})$ or SPOT HRV $(20 \mathrm{~m})$ because of their distinct vegetation that remains largely untouched by land-use change. Several studies have mapped peatlands successfully using automated classification algorithms (Markon and Derksen, 1994; Poulin et al., 2002; Oetter et al., 2001; Bronge and Naslund-Landenmark, 2002; McGovern et al., 2000; Baker et al., 2006). A study in western Siberia employed Russian RESURS-01 images with $150 \mathrm{~m}$ resolution as independent validation for a historical peatland inventory map (Sheng et al., 2004). The comparison 
of spectral reflectance profiles of sphagnum moss and conifer trees showed that sphagnum mosses have a distinct spectral signature with lower reflectance in the near-infrared $(0.70$ $1.3 \mu \mathrm{m})$ and short-wave infrared (1.50-2.5 $\mu \mathrm{m})$ parts of the electromagnetic spectrum (Vogelman and Moss, 1993; Bubier et al., 1997). Taking advantage of this distinct signature and detailed ground measurements, it has proved possible to map shrub and tree LAI on a peatland using multiple endmember spectral unmixing of Landsat data (Cohen et al., 2003; Sonnentag et al., 2007). The success of mapping peatlands at the scale of landscapes and small regions is promising for continental and global scale peatland inventories, however the degree of global relevance of site-specific results remains unknown.

This paper presents the results of a case study that compared data on peatland distribution from several widely used global and continental-scale databases with a detailed land cover map for the St. Petersburg region of Russia (Oetter et al., 2001), examined the spectral characteristics of peatlands in comparison with other common vegetation types in the region using Landsat data and identified approaches for future improved mapping of boreal peatlands based on remotely sensed data.

\section{Study region}

The St. Petersburg region of Russia (Fig. 1) is located on the East-European Plain which is one of the major peatland regions of the world. Situated between $58^{\circ}$ and $62^{\circ} \mathrm{N}$ and between $28^{\circ}$ and $36^{\circ} \mathrm{E}$, the administrative region occupies over $100000 \mathrm{~km}^{2}$, much of that area belongs to the Gulf of Finland of the Baltic Sea and Lake Ladoga, the largest lake in Europe. The influence of these water bodies helps create a maritime climate for the region, with cool wet summers and long cold winters. Mean temperature in July ranges from $16^{\circ}$ to $18^{\circ} \mathrm{C}$, and in January it is $-7^{\circ}$ to $-11^{\circ} \mathrm{C}$. The landscape is typically frozen from November until March, such that much of the annual precipitation of $600-800 \mathrm{~mm}$ falls as snow. The terrestrial part of study area occupies about 8 million hectares of flat terrain that rests on ancient sea sediments covered by a layer of moraine deposits. The natural vegetation belongs to the southern taiga. Fifty-three percent of the region is covered with closed canopy forest, and repeated logging is a major disturbance factor, as is urban expansion and agricultural change (Krankina et al., 2004).

The dominant peatland type in the region is the "raised string bog" (Botch and Masing, 1983). Raised bogs have a dome-shaped surface built up of sphagnum peat. In contrast to minerotrophic fens, raised bogs receive all their water and nutrients from the atmosphere (ombrotrophic). Therefore, they tend to be acidic and low in nutrient availability. Oligotrophic bogs account for about $75 \%$ of the total peat volume in the St. Petersburg region, while transitional peat from mesotrophic peatlands and low-lying peat from fens or

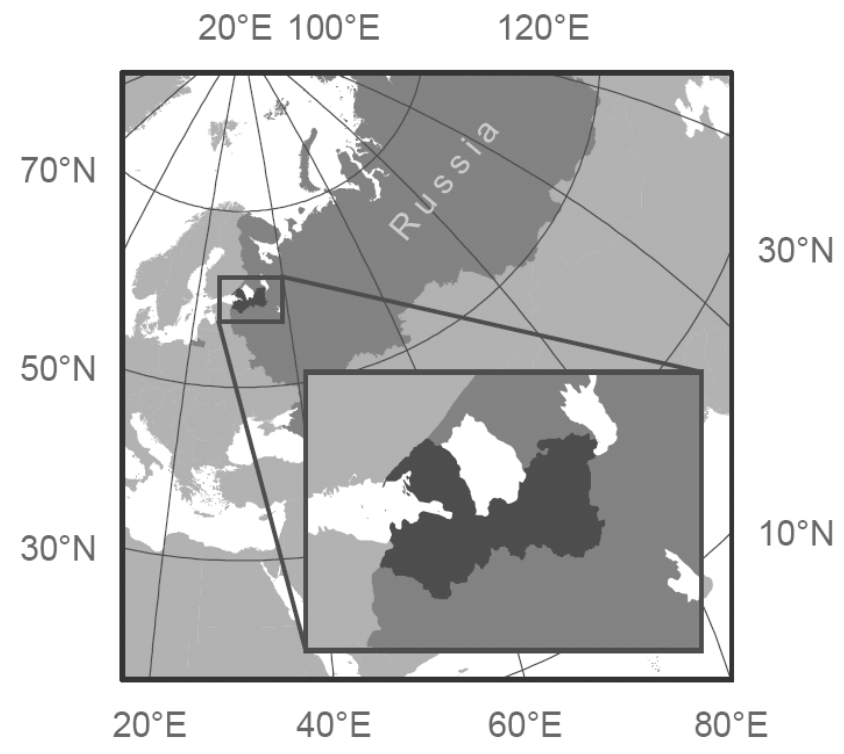

Fig. 1. Study region.

eutrophic peatlands comprise about $14 \%$ and $11 \%$, respectively. In some areas peat is mined for use as fuel or soil additive. Mining removes the upper layers of peat, leaving bare peat surfaces that are often converted to agricultural or forested land.

\section{Cross-comparison of coarse resolution maps and datasets}

Peatlands mapped on a detailed land-cover map of the St. Petersburg region of Russia (Oetter et al., 2001) provided a basis for comparison with maps that cover broader areas at coarser spatial resolution (Table 1). The map was developed based on imagery from the Landsat series of satellites. The imagery selection was initially limited to 1992 1995 to match the time of the ground data collection and was supplemented with scenes from 1986 and 1987. Overall, 12 separate Landsat Thematic Mapper (TM) images and one Multispectral Scanner (MSS) image were acquired to create the map. Geometric rectification was performed by first selecting a map-registered base image (path 182, row 18 for 19 May 1992) that provided the geographic reference to which other images were geometrically corrected. Each of the 14 Landsat images was clipped to the St. Petersburg region boundary and subjected to multiple iterations of unsupervised classification, to construct a map with eight land cover classes (Agriculture, Bogs/other peatlands, Built/Urban, Cloud, Forest, Shadow, Shrub/grass, and Water). In addition, expert judgment of the raw imagery and a hand-drawn map of wetlands (M. Botch, personal communication) was used for visual reference. Bogs and other peatlands that had visual indications of human manipulation 
Table 1. Assessment of peatland representation on coarse-resolution maps and on Landsat-based LARSE land cover map (Oetter et al., 2001) for the St. Petersburg region of Russia.

\begin{tabular}{|c|c|c|c|c|c|c|}
\hline \multirow[t]{2}{*}{ Map and reference } & \multirow{2}{*}{$\begin{array}{l}\text { Spatial } \\
\text { resolution }\end{array}$} & \multirow{2}{*}{$\begin{array}{l}\text { Wetland } \\
\text { area }\left(\mathrm{km}^{2}(\%)\right)\end{array}$} & \multirow[t]{2}{*}{ Relevant class labels (\% of land area) } & \multicolumn{3}{|c|}{ Agreement with LARSE land cover map } \\
\hline & & & & $\begin{array}{l}\text { Area } \\
\left(\mathrm{km}^{2}\right)\end{array}$ & $\begin{array}{l}\text { Omission } \\
\text { error }(\%)\end{array}$ & $\begin{array}{l}\text { Comission } \\
\text { error }(\%)\end{array}$ \\
\hline $\begin{array}{l}\text { LARSE land cover } \\
\text { Oetter et al. (2001) }\end{array}$ & $28.5 \mathrm{~m}$ & $6810(9.7)$ & $\begin{array}{l}\text { Peatlands, unmined }(8.82 \%) \\
\text { and mined }(0.86 \%)\end{array}$ & N/A & N/A & N/A \\
\hline $\begin{array}{l}\text { GLC2000 Northern Eurasia } \\
\text { Bartalev et al. (2003) }\end{array}$ & $1 \mathrm{~km}$ & $2863(4.1)$ & $\begin{array}{l}\text { Bogs and Marsh }(4.0 \%), \\
\text { Palsa bogs }(0.02 \%), \\
\text { Riparian vegetation }(0.02 \%)\end{array}$ & 1529 & 77 & 47 \\
\hline $\begin{array}{l}\text { MODIS IGBP land cover } \\
\text { Friedl et al. (2002) }\end{array}$ & $1 \mathrm{~km}$ & $138(0.2)$ & Permanent wetlands $(0.2 \%)$ & 39 & 99 & 72 \\
\hline $\begin{array}{l}\text { BALANS land cover } \\
\text { Malmberg (2001) }\end{array}$ & $150 \mathrm{~m}$ & $3113(4.4)$ & Wetland (4.4\%) & 1742 & 74 & 44 \\
\hline $\begin{array}{l}\text { LARSE peatland cover } \\
\text { Pflugmacher et al. (2007) }\end{array}$ & $1 \mathrm{~km}$ & $7004(9.8)$ & $\begin{array}{l}\text { Peatlands, unmined }(8.8 \%) \\
\text { and mined }(1.0 \%)\end{array}$ & 4046 & 41 & 42 \\
\hline
\end{tabular}

(draining and peat mining) were manually recoded to a separate class. The overall accuracy of this map was assessed to be $88 \%$. The map is available online http://www.fsl.orst.edu/ larse/russia/.

Information relevant to understanding the global distribution of peatlands and wetlands can be obtained from multiple sources and only some of them are suitable for a meaningful comparison with a detailed regional map of peatlands. For example, Global Distribution of Wetlands (Matthews and Fung, 1987) is a global data base of wetlands at $1^{\circ}$ resolution and it has been developed from the integration of three independent global digital sources: (1) vegetation, (2) soil properties and (3) fractional inundation in each $1^{\circ}$ cell. The integration of these data yielded a global distribution of wetland sites, but the aggregation to $1^{\circ}$ latitude/longitude was too coarse for a meaningful comparison because only eight $1^{\circ}$ cells fit fully within the territory of our study region. We selected the following publicly available coarse-resolution datasets on distribution of peatlands and wetlands for comparison with the detailed map of peatlands in the St. Petersburg region (Table 1 ):

- Global Land Cover (GLC) 2000 map for Northern Eurasia v. 4 (http://www-tem.jrc.it/glc2000/ ProductGLC2000.htm, Bartalev et al., 2003) was produced using 14 months of pre-processed daily global data acquired by the VEGETATION instrument on board the SPOT 4 satellite between 1 November 1999-31 December 2000. The map has 1-km nominal resolution and uses a legend based on LCCS (DiGregorio, 2005). Among the mapped vegetation types, three were relevant to this study: bogs and marsh, palsa bogs, and riparian vegetation.

- MODIS Land Cover IGBP 2001 database (MOD12Q1, V004) was developed by the Boston University Department of Geography and Center for Remote Sensing (http://geography.bu.edu/landcover/) based on MODIS satellite data acquired from 1/1/01 to 12/31/01 (Friedl et al., 2002; http://duckwater.bu.edu/lc/mod12q1.html). The product has a $1-\mathrm{km}$ nominal spatial resolution, and was produced using a supervised classification approach and training sites across the globe. It is available with five legends, but only the IGBP legend includes a class that is relevant to defining peatlands - "permanent wetlands".

- Global Lakes and Wetlands Database (GLWD, Lehner and Doll, 2004; http://www.worldwildlife.org/science/ data/item 1877.html) is a global database compiled from several existing maps and databases including the USGS Global Land Cover Characteristics Database (GLCC.AVHRR, Loveland et al., 2000) described below. Level 3 of this database represents the maximum extent of wetlands and is intended by its authors to serve as an estimate of wetland extents for global hydrology and climatology models, or to identify large-scale wetland distributions and important wetland complexes. 
- BALANS land cover map has been developed from IRS 1C/1D WiFS data with scenes from 1997 up to 2000 for the Baltic Sea basin and ancillary GIS data (Malmberg, 2001; http://www.grida.no/baltic/htmls/arcinfo. $\mathrm{htm})$. The pixel size is $150 \times 150 \mathrm{~m}$.

- LARSE peatland cover is a MODIS-based map of percent peatland cover in $1 \mathrm{~km}^{2}$ pixels for the St. Petersburg region (Pflugmacher at el., 2007). The map was produced by a study that tested the capability of the MODIS sensor to map peatlands within a taiga landscape of the East-European plain. The map represents sub-pixel proportion of peatland cover derived from reference maps and $\sim 1-\mathrm{km}$ resolution MODIS Nadir BRDF-Adjusted Reflectance (NBAR) data from 26 May-9 June 2002. MODIS NBAR is a composite of multi-date, cloud-cleared and atmospherically corrected surface reflectance normalized to the mean solar zenith angle of a 16-day period (Schaaf et al., 2002). The map predicts unmined and mined peatland cover with a rootmean-squared error of $16 \%$ and $9 \%$, respectively. The ground data set used to produce this map was separate from that involved in production and accuracy assessment of the Landsat-based land cover map (Oetter et al., 2001) which is used in this study as a basis for comparison.

Several additional datasets were reviewed including GLCC-AVHRR database based on AVHRR data acquired from April 1992 through March 1993 (Loveland et al., 2000; http://edcsns17.cr.usgs.gov/glcc/). It has a 1-km nominal spatial resolution and was used to produce a core set of derived thematic maps including a map for Eurasia based on IGBP legend. Since GLCC-AVHRR database (Loveland et al., 2000) was incorporated in GLWD and did not show any wetlands at all on the territory of the St. Petersburg region we opted to use only GLWD.

A mosaic of the MODIS-IGBP map for Eurasia was downloaded in Lambert Azimuthal Equal-area (LAEA) projection with a 930-m spatial resolution. The GLC2000 and GLWD maps were available in Plate Carrée projection. Since the Plate Carrée reference system is not an equal area projection (i.e. raster cells vary in area), we reprojected GLC2000 and GLWD into LAEA, the reference system of the MODISIGBP map. The MODIS-based peatland map by Pflugmacher et al. (2007) was kept in its original Sinusoidal projection, which is also an equal area projection (Snyder, 1987). To compare the detailed Landsat-based land cover map with the coarse resolution maps, the Landsat-based map was then reprojected into the coordinate space of the coarse resolution map (e.g. Sinusoidal for MODIS-based peatland map and LAEA for the others). To match the coarse resolution pixels the Landsat-based map was nearest-neighbor resampled to $30 \mathrm{~m}$. Prior to analysis the correct geolocation of all maps in comparison to the Landsat-based reference map was visually assessed. We found the geolocation error of the BALANS map in some areas to be greater than $10-\mathrm{km}$. Hence, we georectified the BALANS map using 37 ground control points and a second-order polynomial transformation (RMSE $=74.6 \mathrm{~m}$, half the BALANS spatial resolution).

To evaluate the performance of the coarse resolution data sets for mapping extent and distribution of peatlands in the St. Petersburg region we a) calculated and compared the areal extent of peatlands in the region by combining all relevant land cover classes on each map and b) analyzed the spatial agreement of the mapped area of peatlands or relevant proxi classes (e.g., wetlands) with the Landsat-based reference map (Table 1, Fig. 2).

Spatial agreement of thematic maps is commonly assessed using a classification error matrix, which is a cross-tabulation of mapped class labels against the class labels of a reference data set (e.g. numbers of pixels that are labeled $\mathrm{x}$ in map A while being labeled $y$ in map B). Comparing two maps on a pixel-by-pixel and category-by-category basis, however, requires that both maps have the same spatial resolution. As a consequence when maps with differing spatial resolutions are compared, the map with the higher spatial resolution is sometimes spatially aggregated to the coarser resolution by assigning the dominant class to the aggregated pixel (Turner et al., 2000). The disadvantage of this approach is that it assumes some level of homogeneity in the landscape since sub-dominant classes are basically omitted from the comparison. Alternatively, the sub-fractional error matrix compares the areal overlap of two categories (Latifovic and Olthof, 2004) and therefore preserves distributional information of all reference classes. Based on the areal agreement and disagreement between the two maps, percent of omission and commission are then calculated. In our case, omission is the percent of peatland area in the Landsat-resolution map that was not mapped as peatland (omitted) in the coarse resolution data set. Similarly, comission is the percent of peatland area mapped in a coarse resolution data set that was not mapped as peatland by the Landsat-based map. For example, a comission of $40 \%$ means that on average coarse resolution peatland pixels contain $40 \%$ of land cover other than peatlands and $60 \%$ of peatland cover. This method is applicable both to categorical land cover maps (that represent peatlands along with other land cover types) and continuous maps (percent peatland cover). Areas in the Landsat-resolution reference data set that were not mapped (e.g. due to clouds) were excluded from the analysis such that only coarse resolution cells with $99 \%$ and more cloud-free reference data were analyzed.

According to the Landsat-based land cover map, peatlands cover about $10 \%$ of the land area in the St. Petersburg region (Oetter et al., 2001). The same percentage was estimated from the MODIS-based peatland map (Pflugmacher et al., 2007). The agreement between the fractional cover map from Pflugmacher et al. (2007) and the higher resolution map is reasonably good (omission $=41 \%$, comission 


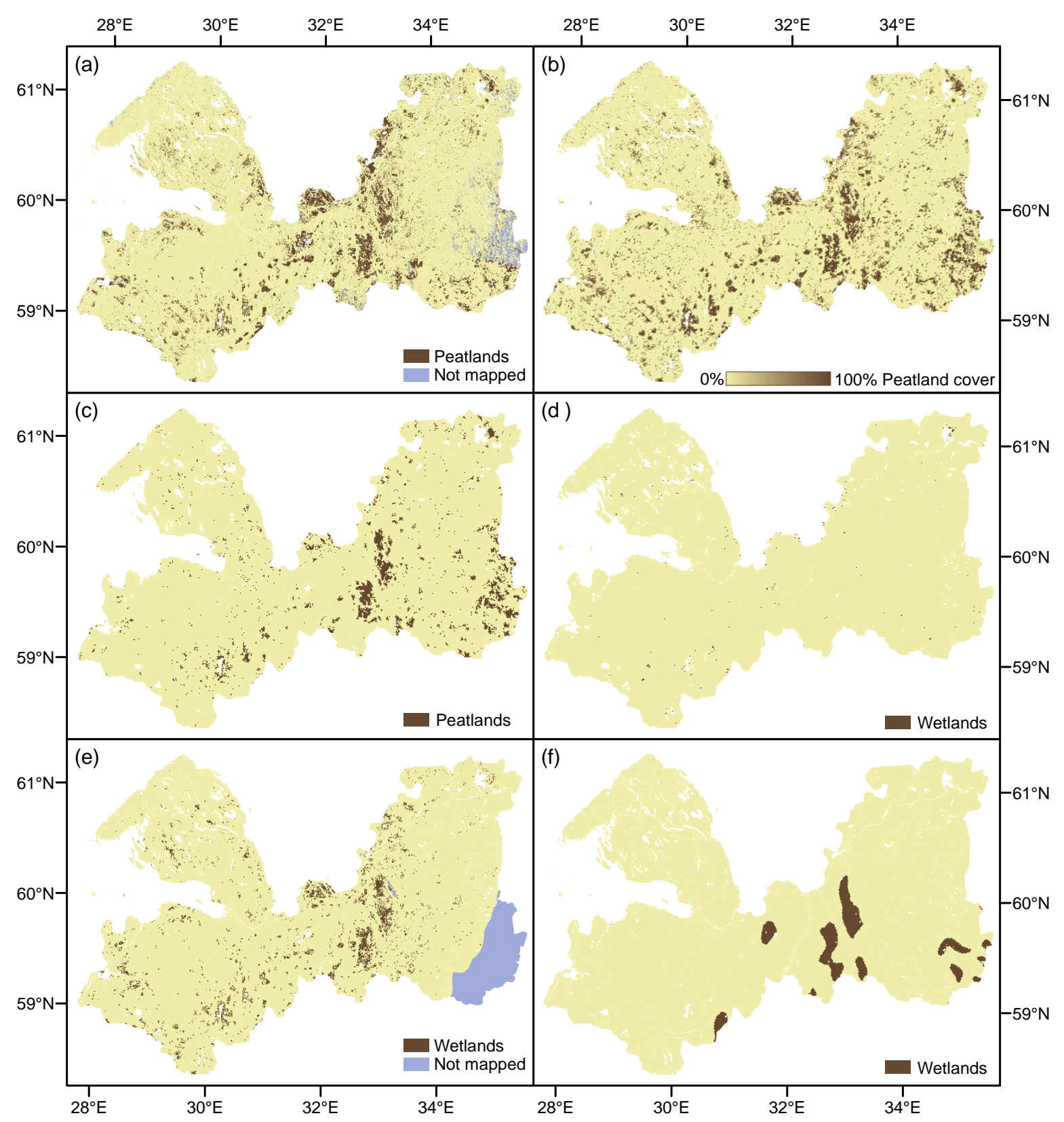

Fig. 2. Peatlands in the St. Petersburg region of Russia - representation on different maps: (a) LARSE land cover (Oetter et al., 2001), (b) LARSE peatland cover (Pflugmacher et al., 2007); (c) GLC2000 Northern Eurasia (Bartalev et al., 2003), (d) MODIS IGBP land cover (Friedl et al., 2002), (e) BALANS land cover (Malmberg, 2001), (f) Global Lakes \& Wetland Database (Lehner and Döll, 2004).

$42 \%$, see Table 1). Furthermore, the spatial patterns of the two maps are similar (Fig. 2a and b). In comparison, the broader regional, continental, and global coarse resolution maps all greatly underestimated peatland cover for the St. Petersburg region. The GLC2000 for Northern Eurasia and BALANS maps (Fig. 2c and e) failed to identify $77 \%$ and $74 \%$ of peatland cover, respectively, when compared to the Landsat-based reference map. According to GLC2000 and BALANS, peatlands account for only $4 \%$ of the land area in the study region, which is less than half of our estimate supported by other regional studies (e.g. Kobak et al., 1998). Nevertheless, the comission error of the two maps is similar to the peatland map from Pflugmacher et al. (2007), which means, that overall, peatlands were correctly classified as such but a large proportion was overlooked (omission error). Interestingly, GLC2000 and BALANS maps both achieved similar agreement with the Landsat-based map even though the BALANS map had a higher spatial resolution $(150 \mathrm{~m}$ 
compared to $1 \mathrm{~km}$ ). Both of these maps were not focused on any particular land cover type and evidently, the lack of focus on peatlands was a more significant factor than resolution in causing the omission in mapping peatlands.

The lowest estimates of peatland area and the lowest agreement with our reference map were observed for the global land cover datasets. The Global Lakes and Wetland Database (GLWD) mapped 3.3\% of the study region as wetland (Fig. 2f) and missed $86 \%$ of peatland area on the reference map. In addition, all wetlands reported for the region by the GLWD were incorrectly classified as freshwater marshes and floodplains while bogs, fens and mires were not reported at all. The MODIS-IGBP land cover mapped $0.2 \%$ of the study area as permanent wetlands (Fig. 2d) and omitted 99\% of peatlands on the Landsat-based reference map.

Both coarse map resolution and class definitions can cause bias towards omission or comission error in representing peatlands on land cover maps. For example, if we counted only the peatland area that occupied more than $50 \%$ of individual $1-\mathrm{km}$ pixels we would only report $3469 \mathrm{~km}^{2}$ of peatlands in the St. Petersburg region (5\% of land area instead of $10 \%$ ). Under the majority rule, all pixels with less than $50 \%$ peatland cover should be classified as some other land cover class (e.g. the dominant class or a mosaic class) and thus half the peatland area would be omitted from the map as the result of the coarse resolution. At the same time, the comission (overestimation) error can occur if for example, a $1-\mathrm{km}$ pixel with $51 \%$ actual peatland cover was correctly mapped as peatland. This would overestimate peatland cover for that pixel by $49 \%$. For the St. Petersburg region, if we account for the effect of commission as the result of a $1-\mathrm{km}$ spatial resolution and assume an omission of peatlands that cover less than $50 \%$ of a $1-\mathrm{km}$ pixel we would report a peatland area of $4627 \mathrm{~km}^{2}$. Therefore categorical maps at $1-\mathrm{km}$ resolution are prone to underestimate peatland area for our study region, even if the mapping algorithm worked perfectly.

The prevalence of omission over comission reflects the characteristic patchiness in the distribution of peatlands in the region with several very large peatlands ( $>1000 \mathrm{ha}$ ) and hundreds of small ones. Because of that there is a high proportion of pixels where peatlands occupy $>75 \%$ of the area thus reducing the potential for comission error and at the same time a fairly high proportion of pixels where peatlands occupy $<50 \%$ and this increases potential for omission error.

Thus, coarse resolution of categorical maps can account for omission of about $50 \%$ of peatlands in our study region. Furthermore, the total area of $1 \mathrm{~km}$ pixels where peatlands occupy $>95 \%$ of each pixel is $719 \mathrm{~km}^{2}$ which is just $1 / 10$ of the total peatland area in the region (Table 1). For maps using the IGBP definition of wetlands as permanently inundated land, this definition appears to be the main factor limiting representation of peatlands as boreal peatlands are not inundated for most of the vegetation season. In an extreme case, no peatlands were mapped for the St. Petersburg re- gion on GLCC-AVHRR database using the IGBP classification (Loveland et al., 2000). A more regionally appropriate class definition of wetlands on GLC2000 map for Northern Eurasia (bogs and mires with no inundation requirement; Bartalev et al., 2003) resulted in a significantly improved representation of peatlands with the level of omission consistent with map resolution. Continuous field modeling used by Pflugmacher et al. (2007) has the potential for a more complete representation of peatlands and other land cover types that occur in small patches. High level of disagreement among land cover maps in regions with significant presence of boreal peatlands (Herold et al., 2008) highlights the challenge of adequate characterization of the global distribution of peatlands.

\section{Spectral reflectance signatures of peatlands from Landsat imagery}

\subsection{Imagery and spectral data processing}

We examined the spectral characteristics of our ground polygons over a spring, summer and autumn season using reflectance data from Landsat TM (19 May 1994) and ETM+ (2 October, 2000; 2 June 2002; WRS-2 path 184, row 18). The three Landsat scenes were acquired at level $1 \mathrm{G}$ processing with a $28.5-\mathrm{m}$ spatial resolution and UTM projection (zone $36 \mathrm{~N}$, WGS84). We used an automated tie-point program from Kennedy and Cohen (2003) to geometrically rectify all images to an orthorectified Landsat scene with an RMSE less than $15 \mathrm{~m}$. The TM image was converted first to at-satellite radiance using parameters from Chander and Markham (2003) and then to surface reflectance using the COST radiometric correction model (Chavez Jr., 1996). The two ETM+ scenes were then radiometrically normalized to the atmospherically corrected TM image using the multiple alteration detection calibration algorithm from Canty (2004). Finally, the six reflectance bands of each image were transformed into Tasseled Cap indices of brightness, greenness, and wetness (Crist, 1985) and average values of these indices were calculated for all pixels within each polygon.

\subsection{Ground data}

Ground information for peatlands and other vegetation types was derived from forest inventory data and maps from 19921993. These maps were based on detailed topographic maps and aerial photographs (Kukuev et al., 1997) and were available as digital vector data with polygons ranging in size from 2.5 to 305 ha. Reference polygons included peatlands and vegetation on mineral soils with similar dominant life forms. Peatlands are classified by forest inventory as bogs and mires when they have less than $40 \%$ tree cover. The percent cover by woody vegetation and the dominant species (primarily Pinus sylvestris L.) was recorded for each polygon. Polygons were grouped into classes depending on presence of tree 


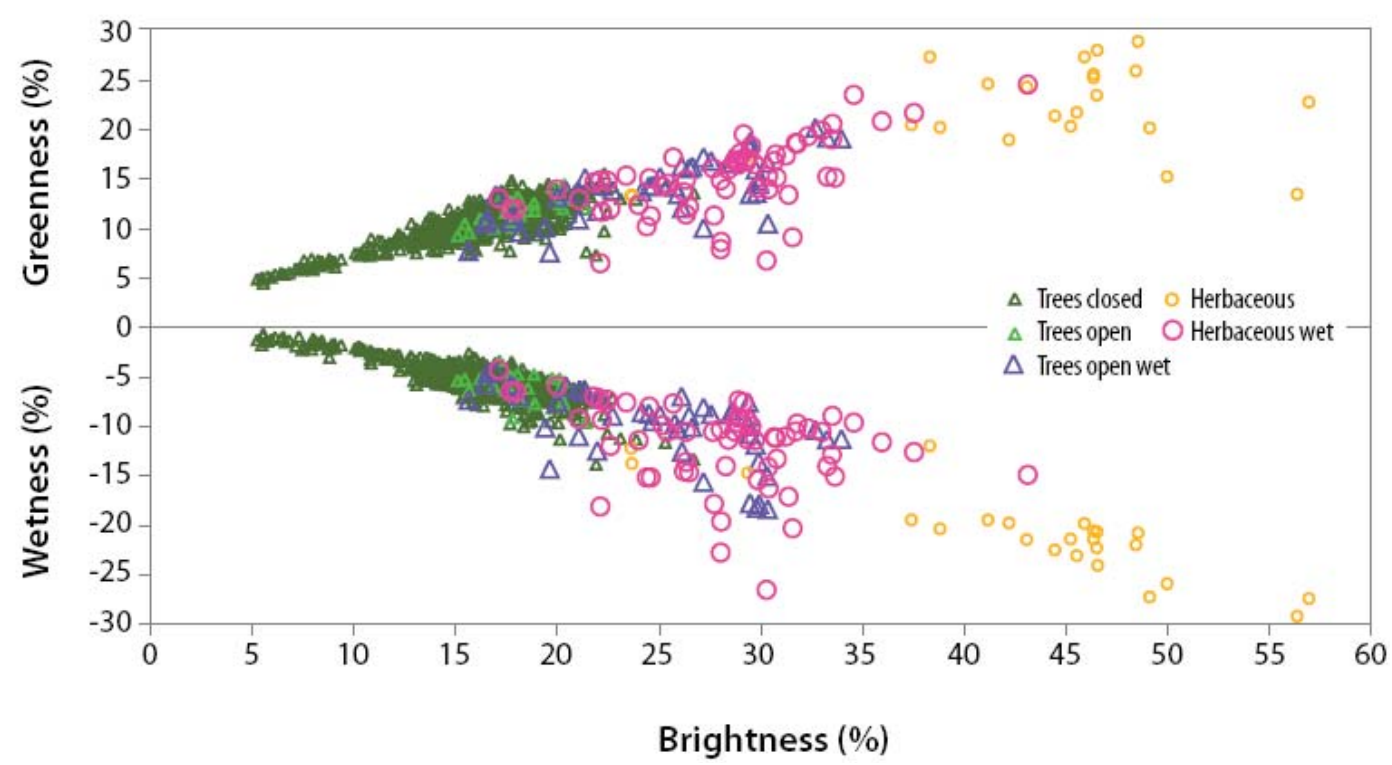

Fig. 3. Average reflectance of ground polygons in Tasselled Cap spectral indices of brightness, greenness, and wetness derived from Landsat ETM+ 2 October 2000.

and shrub cover in line with LCCS (DiGregorio, 2005) with "wet" sub-classes corresponding to peatlands. The following classes were examined:

- Herbaceous-wet (62 polygons) had less than 15\% tree cover. While low shrubs (Vaccinium spp.) are often present, the extent of low shrub cover could not be extracted from available data.

- Herbaceous (25 polygons) were classified by forest inventory as pastures, hay lots, meadows, or glades. Because this class was poorly represented in available forest inventory dataset ( 9 polygons total), 16 additional polygons were hand-digitized using expert judgement and high-resolution imagery (Quickbird) for visual reference.

- Trees-open (22 polygons) - had tree cover between 15 and $65 \%$. Most of these polygons were subject to recent thinning which opened tree canopies.

- Trees-open-wet (46 polygons) - were classified by forest inventory as bogs or mires if the tree cover was between 15 and $40 \%$ or as forest with sphagnum mosses dominating the ground cover and stocking density indicating 50-65\% canopy cover.

- Trees Closed (1528 polygons) - had tree cover greater than $65 \%$ and ground cover other than sphagnum mosses.

- Tree-closed-wet (586 polygons) - had tree cover greater than $65 \%$ and ground cover dominated by sphagnum mosses.

\subsection{Analysis of spectral signatures}

Successful automated mapping of peatlands with spectral imagery requires that peatlands are spectrally separable from other vegetation types. Several studies have demonstrated mapping of peatlands with multi-spectral sensor data of different spatial resolution (Poulin et al., 2002; Oetter et al., 2001; Bronge and Naslund-Landenmark, 2002; McGovern et al., 2000; Baker et al., 2006; Pflugmacher et al. 2007). In the St. Petersburg region, peatlands are fairly distinct in Tasselled Cap (TC) spectral space (Fig. 3). In terms of TC indices of brightness, greenness, and wetness, peatland polygons occupy the space between tree-dominated and herbaceous types on mineral soil. This positioning of peatlands in spectral space suggests that land cover classifications which focus on a single vegetation life form as their organizing principle (i.e., tree, shrub, herbaceous) and do not define peatlands as a distinct cover type will likely split peatland spectral space leading to added confusion among land cover types. The location of areas of disagreement among current global vegetation maps within the boreal forest zone seems to corroborate this (Herold et al., 2008).

The spectral reflectance signatures showed that peatlands can be separated from similar vegetation types on mineral soil except when under closed tree canopy (Fig. 4). The difference in spectral reflectance of treeless peatlands and herbaceous vegetation on mineral soil was the greatest in the near-infrared (0.77-0.90 $\mu \mathrm{m}$, Landsat band 4) in the summer (2-June-2002) and in the near- and shortwave-infrared wavelengths $(0.77-0.99,1.55-1.75,2.08-2.35 \mu \mathrm{m}$, Landsat bands $4,5,7)$ in late spring (19 May 1994) and autumn (2 October 2000). The characteristic seasonal variation was greater 


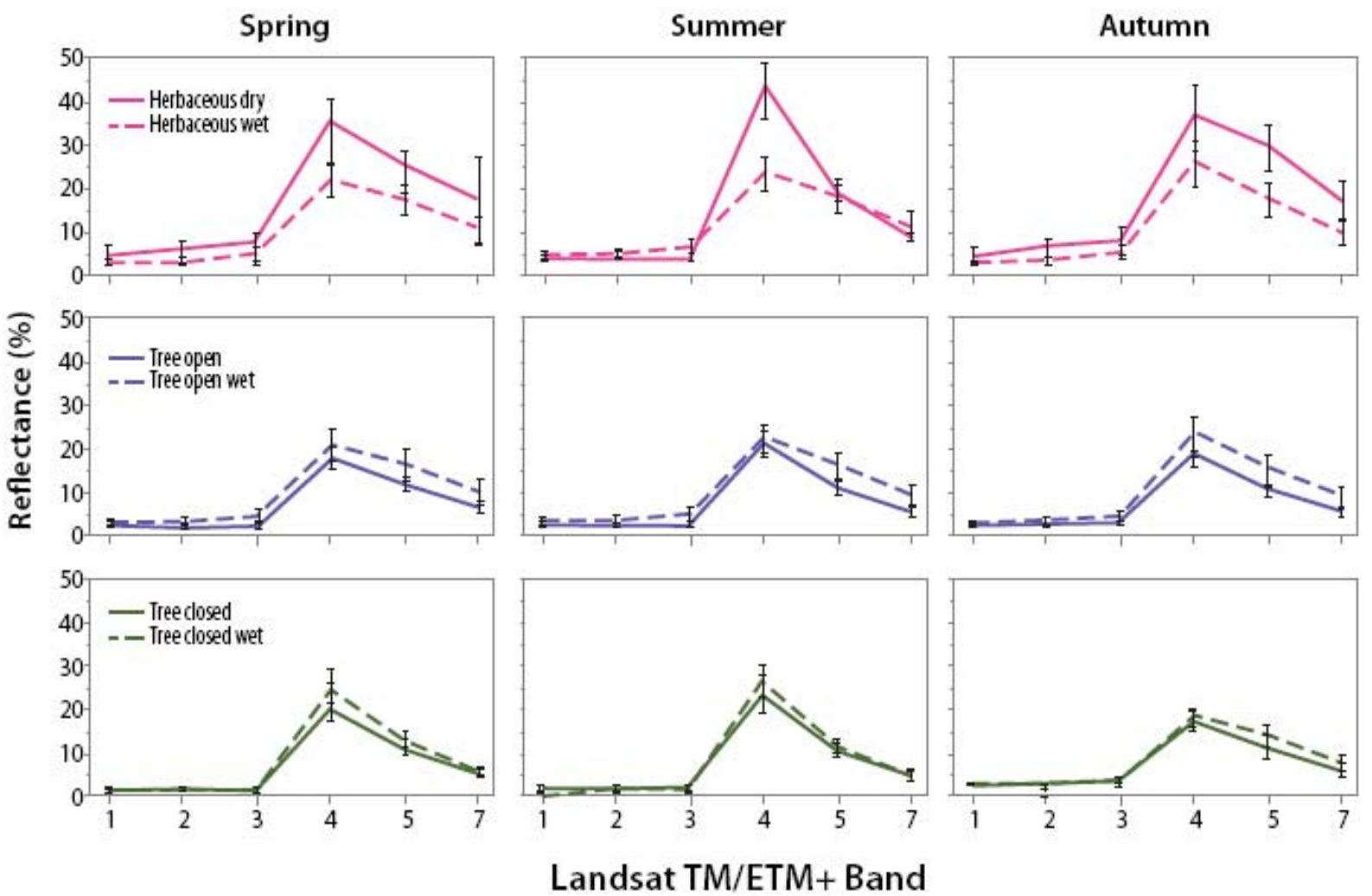

Fig. 4. Mean reflectance and standard deviation (error bars) of different vegetation types as observed in ground polygons. Landsat TM/ETM+ Band 1 is $0.45-0.52 \mu \mathrm{m}$, Band 2 is $0.52-0.60 \mu \mathrm{m}$, Band 3 is $0.63-0.69 \mu \mathrm{m}$, Band 4 is $0.76-0.90 \mu \mathrm{m}$, Band 5 is $1.55-1.75 \mu \mathrm{m}$ and Band 7 is $2.08-2.35 \mu \mathrm{m}$.

for herbaceous vegetation on mineral soil than on peatlands: herbaceous vegetation on peatlands did not exhibit midseason peak as much as herbaceous vegetation on mineral soil. The lower reflectance of peatlands with herbaceous cover in the near- and shortwave-infrared wavelengths $(0.77-$ $2.35 \mu \mathrm{m})$ was consistent with the difference between the spectral signature of sphagnum and vascular plants observed by Vogelman and Moss (1993) and Bubier et al. (1997). However, the difference in the shortwave infrared reflectance disappeared on the summer image (Fig. 4). Seasonal variations in the reflectance spectra are probably the result of phenological differences in the plant communities and the changes in sun-angle. While it is not clear to what extent the same temporal patterns apply to other geographic regions and years, these results suggest that multi-temporal satellite data could improve the mapping of peatlands with spectral satellite data.

The difference in spectral reflectance between open canopy forests on peatlands and on mineral soil was smaller than for herbaceous-dominated land cover types but some separation of these classes seems possible (Fig. 4). The pattern of difference in this case is not consistent with the spectral signature of sphagnum as the reflectance in the nearand shortwave-infrared part of the spectrum was higher for open canopy forests on peatlands than on mineral soil. The likely reason is higher average canopy cover among polygons with open tree stands on mineral soil (46\%) than on peatlands (33\%). Apparently, the canopy architecture in this case has a greater impact on spectral reflectance of polygons than the distinct spectral signature of sphagnum moss. The differences in spectral reflectance among the closed canopy polygons are clearly insufficient to distinguish peatlands with Landsat sensor when closed canopy of trees is present.

\section{Conclusions}

1. Coarse resolution maps of land cover under-represent peatlands in the St. Petersburg region of Russia and in other parts of the boreal zone as well (Frey and Smith, 2007). Coarse resolution $(1 \mathrm{~km})$ of categorical maps alone may be responsible for omission of about $50 \%$ of peatlands in our study region. Maps that define wetlands as inundated lands omit a significant portion of boreal peatlands by definition, while on maps with more inclusive definitions the omission is smaller. Pflugmacher et al. (2007) showed that greatly improved mapping at $1 \mathrm{~km}$ resolution is possible with MODIS sensor and continuous field approach targeting boreal peatlands. 
2. Peatlands occupy spectral space that is fairly distinct from similar vegetation types on mineral soil except when under closed tree canopy. This indicates the potential of spectral data to provide basis for improved mapping of peatlands with sparse or absent tree cover. The lower reflectance of treeless peatlands in the near- and shortwave-infrared part of the electromagnetic spectrum is consistent with the spectral signature of sphagnum mosses. However, when trees are present, the canopy architecture appears to be more important than the spectral signature of sphagnum mosses in defining the overall spectral reflectance of peatlands.

3. The seasonal pattern of change in peatlands with herbaceous cover is distinct from the seasonal change in herbaceous vegetation on mineral soil. The mid-season peak in the near-infrared part of the electromagnetic spectrum is a characteristic feature of herbaceous cover on mineral soil but not on peatlands. Thus, multitemporal satellite observations could help in improving peatland mapping.

4. Major under-representation of boreal peatlands on currently available global data sets reflects the impact of coarse resolution of categorical maps, the limitations of commonly used classification of land cover and the lack of research focus on developing remote sensing methods targeting peatlands. Under-representation of the actual extent of peatlands leads to inadequate representation of their global role even as the models of the peatland response to global change improve.

5. Remotely sensed data provides a globally consistent source of information from which a globally consistent and spatially explicit data on distribution of peatlands can be extracted. The legacy datasets (e.g., GLWD, national peatland inventories) can play an important role in supporting the development of methods for remote sensing of peatlands by providing a globally distributed set for calibration and validation of new maps. Continuous field mapping and explicit use of regionally appropriate proxi variables can help address some of the known limitations of available maps. Improved mapping of boreal peatlands with spectral sensors, alone or in combination with radars, is feasible and important for understanding of one of the major feedbacks of terrestrial biota to global climate change.

6. Successful use of remotely sensed data for local and regional peatland mapping provides knowledge base from which methods for continental and global mapping can be developed. Meeting the challenge of global mapping of peatlands with remotely sensed data requires an interdisciplinary research effort which includes peatland ecologists, global biogeochemists, and remote sensing experts.
Acknowledgements. This research was conducted with support from the Land Cover/Land-Use Change Program of the National Aeronautics and Space Administration (grant number NNG06GF54G). The paper is prepared as a contribution to Biogeosciences Discussions - Special Issue "Peatlands and the carbon cycle - from local processes to global implications". We greatly appreciate the support and encouragement of Gabriela Schaepman, Juul Limpens, and other organizers and participants of the Symposium on Carbon in Peatlands (Wageningen, 15-18 April 2007). The authors thank OSU students Mikhail Yatskov and Joy Morton for their technical assistance in preparation of this manuscript. We also thank referees for assisting in evaluating this paper.

Edited by: T. Laurila

\section{References}

Anisimov, O. A., Vaughan, D. G., Callaghan, T. V., Furgal, C., Marchant, H., Prowse, T. D., Vilhjálmsson, H., and Walsh, J. E.: Polar Regions (Arctic and Antarctic), in: Climate Change 2007, Impacts, Adaptation and Vulnerability, Contribution of Working Group II to the Fourth Assessment Report of the Intergovernmental Panel on Climate Change, edited by: Parry, M. L., Canziani, O. F., Palutikof, J. P., Van der Linden, P. J., and Hanson, C. E., Cambridge University Press, Cambridge, United Kingdom, 653685, 2007.

Bartalev, S. A., Belward, A. S., Erchov, D. V., and Isaev, A. S.: A new Spot4-Vegetation Derived Land Cover Map of northern Eurasia, Int. J. Remote Sens., 24, 1977-1982, 2003.

Bartolome, E. and Belward, A. S.: GLC2000: A new approach to global land cover mapping from Earth observation data, Int. J Remote Sens., 26, 1959-1977, 2005.

Baker, C., Lawrence, R., Montague, C., and Patten, D.: Mapping wetlands and riparian areas using landsat etm+ imagery and decision-tree-based models, Wetlands, 26, 465-474, 2006.

Beilman, D. W., Vitt, D. H., Bhatti, J. S., and Forest, S.: Peat carbon stocks in the southern Mackenzie river basin, Uncertainties revealed in a high-resolution case study, Global Change Biol., 14, 1221-1232, 2008.

Botch, M. S. and Masing, V. V.: Mire Systems in the USSR, in: Ecosystems of the World, 4B, Mire: Swamp, Bog, Fen and Moor, edited by: Gore, A. J. P., Elsevier, Amsterdam, 95-152, 1983.

Bridgham, S. D., Megonigal, J. P., Keller, J. K., Bliss, N. B., and Trettin, C.: Chapter 13, Wetlands (The First State of the Carbon Cycle Report), US Climate Change Science Program, Synthesis and Assessment Product 2.2, 2007.

Bronge, L. B. and Naslund-Landenmark, B.: Wetland classification for swedish corine land cover adopting a semi-automatic interactive approach, Can. J. Remote Sens., 28, 139-155, 2002.

Bubier, J. L., Rock, B. N., and Crill, P. M.: Spectral reflectance measurements of boreal wetland and forest mosses, J. Geophys Res.-Atmos., 102, 29483-29494, 1997.

Canty, M. J., Nielsen, A. A., and Schmidt, M.: Automatic radiometric normalization of multispectral imagery, Remote Sens. Environ., 91, 441-451, 2004.

Chander, G. and Markham, B. L.: Revised Landsat 5 TM radiometric calibration procedures and post-calibration dynamic ranges, IEEE Transact. Geosci., 41, 2674-2677, 2003. 
Chavez Jr., P. S.: Image-based atmospheric corrections - revisited and improved, Photogramm. Eng. Rem. S., 62, 1025-1036, 1996.

Cohen, W. B., Maiersperger, T. K., Gower, S. T., and Turner, D. P.: An improved strategy for regression of biophysical variables and Landsat ETM+ data, Remote Sens. Environ., 84, 561-571, 2003.

Crist, E. P.: A TM tasseled cap equivalent transformation for reflectance factor data, Remote Sens. Environ., 17, 301-306, 1985.

DeFries, R. S., Hansen, M., Steininger, M., Dubayah, R., Sohlberg, R., and Townshend, J. R. G.: Subpixel forest cover in central Africa from multisensor, multitemporal data, Remote Sens. Environ., 60, 228-246, 1997.

Denman, K. L., Brasseur, G., Chidthaisong, A., Ciais, P., Cox, P. M., Dickinson, R. E., Hauglustaine, D., Heinze, C., Holland, E., Jacob, D., Lohmann, U., Ramachandran, S., da Silva Dias, P. L., Wofsy, S. C., and Zhang, X.: Couplings Between Changes in the Climate System and Biogeochemistry, in: Climate Change, The Physical Science Basis, Contribution of Working Group I to the Fourth Assessment Report of the Intergovernmental Panel on Climate Change, edited by: Solomon, S., Qin, D., Manning, M., Chen, Z., Marquis, M., Averyt, K. B., Tignor, M., and Miller, H. L., Cambridge University Press, Cambridge, United Kingdom and New York, NY, USA, 2007.

Di Gregorio, A.: Land Cover Classification System, Classification Concepts and User Manual for Software (Version 2), Environment and Natural Resources Service Series, No. 8, FAO, Rome, Italy, 208 pp., 2005.

Frey, K. E. and Smith, L. C.: How well do we know northern land cover? Comparison of four global vegetation and wetland products with a new ground-truth database for West Siberia, Global Biogeochem. Cy., 21, GB1016, doi:10.1029/2006GB002706, 2007

Friedl, M. A., McIver, D. K., Hodges, J. C. F., Zhang, X. Y., Muchoney, D., Strahler, A. H., Woodcock, C. E., Gopal, S., Schneider, A., Cooper, A., Baccini, A., Gao, F., and Schaaf, C.: Global land cover mapping from MODIS, Algorithms and early results, Remote Sens. Environ., 83, 287-302, 2002.

Frolking, S., Roulet, N., and Fuglestvedt, J: How northern peatlands influence the earth's radiative budget, Sustained methane emission versus sustained carbon sequestration, J. Geophys. Res.Biogeosciences, 111, G01008, doi:10.1029/2005JG000091, 2006.

Gorham, E.: Northern peatlands: Role in the carbon cycle and probable responses to climatic warming, Ecol. Appl, 1, 182-195, 1991.

Häme, T., Stenberg, P., Andersson, K., Rauste, Y., Kennedy, P., Folving, S., and Sarkeala, J.: AVHRR-based forest proportion map of the Pan-European area, Remote Sens. Environ., 77, 7691, 2001.

Hansen, J., Sato, M., Ruedy, R., Lacis, A., and Oinas, V.: Global warming in the twenty-first century, An alternative scenario, Proc. Natl. Acad. Sci., 97, 9875-9880, doi:10.1073/pnas.170278997, 2000.

Hansen, M. C., Townshend, J. R. G., DeFries, R. S., and Carroll, M.: Estimation of tree cover using MODIS data at global, continental and regional/local scales, Int. J. Remote Sens., 26, 4359-4380, 2005.

Herold, M., Mayaux, P., Woodcock, C. E., Baccini, A., and Schmullius, C.: Some challenges in global land cover mapping, An as- sessment of agreement and accuracy in existing $1 \mathrm{~km}$ datasets, Earth Observations for Terrestrial Biodiversity and Ecosystems Special Issue, Rem. Sens. Environ., 112(5), 2538-2556, 2008.

Kennedy, R. E. and Cohen, W. B.: Automated designation of tiepoints for image-to-image coregistration, Int. J. Remote Sens. 24, 3467-3490, 2003.

Kobak, K. I., Kondrasheva, N. Y., and Turchinovich, I. E.: Changes in carbon pools of peatland and forest in northwestern Russia during the Holocene, Global Planet. Change, 16/17, 75-84, 1998.

Krankina, O. N., Bergen, K. M., Sun, G., Masek, J. G., Shugart, H. H., Kharuk, V., Kasischke, E., Cohen, W. B., Oetter, D. R., and Duane, M. V.: Northern Eurasia, Remote sensing of boreal forests in selected regions, in: Land Change Science, Observing, Monitoring, and Understanding Trajectories of Change on the Earth's Surface, edited by: Gutman, G., Janetos, A. C., Justice, C. O., Moran, E. F., Mustard, J. F., Rindfuss, R. R., Skole, D., Turner, II, B. L., and Cochrane, M. A., Springer, Berlin, 123138, 2004.

Kukuev, Y. A., Krankina, O. N., and Harmon, M. E.: The forest inventory system in Russia, J. Forestry, 95, 15-20, 1997.

Latifovic, R. and Olthof, I.: Accuracy assessment using sub-pixel fractional error matrices of global land cover products derived from satellite data, Remote Sens. Environ., 90, 153-165, 2004.

Li, J. H. and Chen, W. J.: A rule-based method for mapping Canada's wetlands using optical, radar and DEM data, Int. J. Remote Sens., 26, 5051-5069, 2005.

Loveland, T. R., Reed, B. C., Brown, J. F., Ohlen, D. O., Zhu, Z., Yang, L., and Merchant, J. W.: Development of a global land cover characteristics database and IGBP DISCover from 1-km AVHRR data, Int. J. Remote Sens., 21, 1303-1330, 2000.

Lehner, B. and Doll, P.: Development and validation of global databases of lakes, reservoirs and wetlands, J. Hydrol., 296, 122, 2004.

Malmberg, U.: BALANS land cover and land use classification methodology, Environmental Climate Programme, Novosat Oy, BALANS report Balans-utv-24 2.0, Stockholm, 2001.

Markon, C. J. and Derksen, D. V.: Indentification of tundra landcover near Teshekpuk Lake, Alaska using spot satellite data, Arctic, 47, 222-231, 1994.

McGovern, E. A., Holden, N. M., Ward, S. M., and Collins, J. F.: Remotely sensed satellite imagery as an information source for industrial peatlands management, Resour. Conserv. Recycl., 28, 67-83, 2000.

McGuire, A. D., Wirth, C., Apps, M., Beringer, J., Clein, J., Epstein, H., Kicklighter, D. W., Bhatti, J., Chapin, III, F. S., de Groot, B., Efremov, D., Eugster, W., Fukuda, M., Gower, T., Hinzman, L., Huntley, B., Jia, G. J., Kasischke, E., Melillo, J., Romanovsky, V., Shvidenko, A., Vaganov, E., and Walker, D.: Environmental variation, vegetation distribution, carbon dynamics and water/energy exchange at high latitudes, J. Veg. Sci., 13, 301-314, 2002.

McGuire, A. D., Chapin, F. S. III, Wirth, C., Apps, M., Bhatti, J., Callaghan, T., Christensen, T. R., Clein, J. S., Fukuda, M., Maximov, T., Onuchin, A., Shvidenko, A., and Vaganov, E.: Responses of high latitude ecosystems to global change, Potential consequences for the climate system, in: Terrestrial Ecosystems in a Changing World, edited by: Canadell J. G., Pataki, D. E., and Pitelka, L. F., 297-310, The IGBP Series, Springer-Verlag, 
Berlin Heidelberg, 2007.

Matthews, E.: Global data bases on distribution, characteristics and methane emission of natural wetlands, Documentation of archived data tape, NASA Goddard Space Flight Center, Greenbelt, MD, USA, NASA Technical Memorandum, 4153, 1989.

Matthews, E. and Fung, I.: Methane emission from natural wetlands, Global distribution, area, and environmental characteristics of sources, Global Biogeochem. Cycles, 1, 61-86, 1987.

Oetter, D. R., Krankina, O. N., Cohen, W. B., and Majersperger, T. K.: Using landsat thematic mapper data to map land cover and biomass in a Russian forest for regional carbon storage inventory, Global Change Open Science Conference, Amsterdam, The Netherlands, 10-13 July, 2001.

Pflugmacher, D., Krankina, O. N., and Cohen, W. B.: Satellitebased peatland mapping, Potential of the MODIS sensor, Global Planet. Change, 56, 248-257, 2007.

Pastor, J., Solin, J., Bridgham, S. D., Updegraff, K., Harth, C., Weishampel, P., and Dewey, B.: Global warming and the export of dissolved organic carbon from boreal peatlands, Oikos, 100, 380-386, doi:10.1034/j.1600-0706.2003.11774.x, 2003.

Poulin, M., Careau, D., Rochefort, L., and Desrochers, A.: From Satellite Imagery to Peatland Vegetation Diversity: How Reliable Are Habitat Maps?, Cons. Ecol., 6(2), 16, http://www.consecol. org/vol6/iss2/art16, 2002.

Prigent, C., Papa, F., Aires, F., Rossow, W. B., and Matthews, E.: Global inundation dynamics inferred from multiple satellite observations, J. Geophys. Res., 112, D12107, doi:10.1029/2006JD007847, 2007.

Rosenqvist, A., Finlayson, C. M., Lowry, J., and Taylor, D.: The potential of long-wavelength satellite-borne radar to support implementation of the Ramsar Wetlands Convention, Aquat. Conserv., 17, 229-244, 2007.

Roulet, N. T.: Peatlands, carbon storage, greenhouse gases, and the Kyoto Protocol, prospects and significance for Canada, Wetlands, 20, 605-615, 2000.
Rydin, H. and Jeglum, J.: The biology of peatlands, Oxford University Press Inc., New York, US, 343 pp., 2006.

Schaaf, C. B., Gao, F., Strahler, A. H., Lucht, W., Li, X., Tsang, T., Strugnell, N. C., Zhang, X., Jin, Y., Muller, J.-P., Lewis, P., Barnsley, M., Hobson, P., Disney, M., Roberts, G., Dunderdale, M., Doll, C., d'Entremont, R. P., Hu, B., Liang, S., Pivette, J. L., Roy, D. P.: First operational BRDF, albedo nadir reflectance products from MODIS, Remote Sens. Environ., 83, 135-148, 2002.

Sheng, Y., Smith, L. C., MacDonald, G. M., Kremenetski, K. V., Frey, K. E., Velichko, A. A., Lee, M., Beilman, D. W., and Dubinin, P.: A high resolution GIS-based inventory of the West Siberian peat carbon pool, Global Biogeochem. Cy., 18, GB3004, doi:10.1029/2003GB002190, 2004.

Smith, L. C., MacDonald, G. M., Velichko, A. A., Beilman, D. W., Borisova, O. K., Frey, K. E., Kremenetski, K. V., and Sheng, Y.: Siberian peatlands a net carbon sink and global methane source since the Early Holocene, Science, 303, 353-356, 2004.

Snyder, J. P.: Map Projections: A Working Manual, in: Washington, D.C., edited by: U.S.G. Survey, United States Geological Survey, 1987.

Sonnentag, O., Chen, J. M., Roberts, D. A., Talbot, J., Halligan, K. Q., and Govind, A.: Mapping tree and shrub leaf area indices in an ombrotrophic peatland through multiple endmember spectral unmixing, Remote Sens. Environ., 109, 342-360, 2007.

Sturm, M., Racine, C., and Tape, K.: Increasing shrub abundance in the Arctic, Nature, 411, 546-547, 2001.

Turner, D. P., Cohen, W. B., and Kennedy, R. E.: Alternative spatial resolutions and estimation of carbon flux over a managed forest landscape in western Oregon, Landscape Ecol., 15, 441-452, 2000.

Vogelmann, J. E. and Moss, D. M.: Spectral reflectance measurements in the Genus Sphagnum, Remote Sens. Environ., 45(3), 273-279, 1993. 